\title{
Ekstirpasi Hemangioma di Dinding Lateral Hidung dengan Pendekatan Endoskopi
}

\author{
Bestari Jaka Budiman, Al Hafiz
}

\begin{abstract}
Abstrak
Pendahuluan: Hemangioma di dinding lateral hidung merupakan kasus tumor jinak pembuluh darah yang jarang angka kejadiannya. Metode: Pendekatan endoskopi memberikan hasil yang lebih baik pada penatalaksanaan kasus tumor jinak di daerah hidung dan sinus paranasal. Pada kasus-kasus tertentu, pendekatan endoskopi memberikan beberapa keuntungan lebih, seperti dapat mengangkat massa tumor dengan morbiditas yang rendah dan menghindari kerusakan yang tidak perlu pada mukosa dan struktur anatomi yang sehat. Diskusi: Telah dilakukan pengangkatan hemangioma di dinding lateral hidung dengan pendekatan endoskopi pada seorang pasien wanita berusia 33 tahun.
\end{abstract}

Kata kunci: hemangioma, dinding lateral hidung, pendekatan endoskopi

\begin{abstract}
Introduction: The hemangioma in the lateral wall of the nose is an uncommon benign vascular neoplasm. Methods: The endoscopic approach can be succesfully employed for the treatment of benign tumor of the nose and paranasal sinuses. In selected cases, this surgical technique allows the complete removal of the tumor with less morbidity, and avoidance of unnecessary resection of healthy mucosa and anatomy structures. Discussion: A case of endoscopic management of a hemangioma in the lateral wall of the nose in a 33 years old girl is reported.
\end{abstract}

Keywords:hemangioma, lateral wall of the nose, endoscopic approach

Affiliasi penulis :Bagian THT-KL Fak. Kedokteran Univ. Andalas Korespondensi :dr_hafizdjosan@yahoo.com

\section{Pendahuluan}

Adanya massa intranasal harus dibedakan sebagai suatu massa tumor atau proses inflamasi. Tumor intranasal seperti papiloma intranasal, capillary hemangioma, osteoma, karsinoma sel skuamosa, melanoma dan angiosarkoma. Sedangkan massa sebagai akibat suatu proses infalamasi, dapat ditemukan pada kasus sarkoidosis, sindroma Wagener. ${ }^{1}$ Pada anak-anak harus difikirkan suatu benda asing di kavum nasi, yang pada beberapa kasus memiliki tampilan klinis menyerupai hemangioma. ${ }^{1,2}$

Untuk daerah kepala dan leher, hemangioma merupakan tumor jinak pembuluh darah daerah yang paling sering muncul. $60 \%$ tumor ini berkembang di regio kepala dan leher. $^{3} 30 \%$ hemangioma sudah terlihat saat lahir. ${ }^{4}$ Lebih $70 \%$ mengalami regresi pada usia 7 tahun. ${ }^{5}$

Pada umumnya hemangioma ini terjadi pada bagian-bagian tubuh yang mudah terkena trauma, seperti tangan dan kaki, walaupun ada juga yang menemukan terjadi di ginggiva. Faktor hormonal diduga juga berperan. Hal ini terlihat pada granuloma gravidarum dimana ditemukan hemangioma pada ginggiva wanita hamil. ${ }^{1}$

Etiologi hemangioma secara umum belum diketahui secara pasti. Begitu juga dengan hemangioma di daerah kepala dan leher. Dicurigai kelainan kongenital dan adanya riwayat trauma daerah kepala dan leher sebagai faktor etiologi. ${ }^{6}$

Meskipun jarang, hemangioma intranasal atau sinus paranasal dapat menjadi masalah yang serius. Pasien datang dengan keluhan hidung berdarah atau epistaksis yang berulang. ${ }^{1}$ Epistaksis dan hidung tersumbat merupakan gejala utama pada pasien hemangioma intranasal. ${ }^{7}$ Stamataki (2008), telah melaporkan kasus hemangioma intranasal dengan gejala klinis yang lebih berat seperti terjadinya penekanan terhadap rongga hidung dan sinus paranasal oleh massa hemangioma, serta mengganggu fungsi saraf kranialis. ${ }^{6}$

Penatalaksanaan hemangioma masih merupakan hal yang kontroversi. Pendekatan eksternal mulai ditinggalkan dan beralih ke pendekatan dengan menggunakan endoskopi. Satu dekade terakhir, pendekatan endoskopi telah banyak terbukti sukses mengangkat tumor jinak seperti inverted papiloma, lesi pembuluh darah, tumor fibroosseus, pleomorfik adenoma, glioma dan skwanoma. ${ }^{8}$ Pada beberapa kasus, teknik operasi ini, dapat mengangkat tumor secara penuh, angka morbiditas yang rendah, angka perawatan di RS yang lebih singkat, kehilangan darah yang lebih sedikit, serta visualisasi yang lebih baik. ${ }^{4,8}$

Pada laporan kasus ini dicoba mendiskripsikan bedah endoskopi untuk mengangkat hemangioma di dinding lateral hidung. Disamping itu, dalam kasus ini juga dibandingkan beberapa literatur tentang teknik operasi lain. Hal ini berguna untuk membandingkan kelebihan dan kekurangan masingmasing pendekatan tersebut.

\section{Laporan Kasus}

Pada tanggal 30 Mei 2011, seorang pasien perempuan umur 33 tahun datang ke Poliklinik rawat jalan THT RSUP Dr. M. Djamil Padang dengan keluhan utama hidung keluar darah dari hidung sebelah kiri sejak 2 hari yang lalu. Sebelumnya pasien sedang beraktivitas di rumah, tiba-tiba dari hidung sebelah kiri keluar darah sebanyak $1 / 2$ cangkir. Lalu pasien dibawa ke RSUD Lubuk Basung. Perdarahan 
berhenti spontan. Pasien juga pernah dirawat dengan keluhan yang sama 3 bulan yang lalu selama 2 hari di RSUD Lubuk Basung. Pulang atas permintaan sendiri. Riwayat adanya trauma daerah hidung luar atau rongga hidung disangkal. Keluhan hidung tersumbat tidak ada. Hidung berair tidak ada. Riwayat bersin-bersin berulang bila cuaca dingin atau terkena debu disangkal. Ada rasa dahak mengalir di belakang tenggorok disangkal.

Telinga berdenging dan pandangan ganda tidak ada. Riwayat hipertensi tidak ada. Riwayat trauma tidak ada. Sesak nafas tidak ada. Suara serak tidak ada, benjolan di leher tidak ada. Tidak ada mengalami penurunan berat badan sejak menderita penyakit ini.

Pasien adalah seorang ibu rumah tangga. Tidak ada riwayat penyakit lain sebelumnya. Dalam keluarga tidak ada riwayat penyakit keganasan.

Pada pemeriksaan fisik didapatkan keadaan umum sedang, kesadaran komposmentis, kooperatif, tidak demam.

Pada pemeriksaan hidung luar, tidak ditemukan deformitas, tidak tampak massa dan tidak terdapat penonjolan di pipi. Pada pemeriksaan rinoskopi anterior dan nasoendoskopi hidung sebelah kiri, kavum nasi sempit, konka media dan inferior edema, ditemukan adanya krista di septum nasi. Tampak massa di daerah sepertiga posterior kavum nasi sinistra. Massa berbenjol-benjol, melekat ke arah dinding lateral hidung, berwarna kemerahan dan mudah berdarah (Gambar 1). Hidung sebelah kanan, kavum nasi sempit, konka media dan inferior edema, ditemukan adanya krista. Tak tampak adanya massa. Tidak terdapat penonjolan di palatum dan rongga mulut. Pemeriksaan telinga dan tenggorok tidak didapatkan kelainan. Tidak terdapat gangguan buka mulut. Tidak terdapat pembesaran kelenjar getah bening leher.

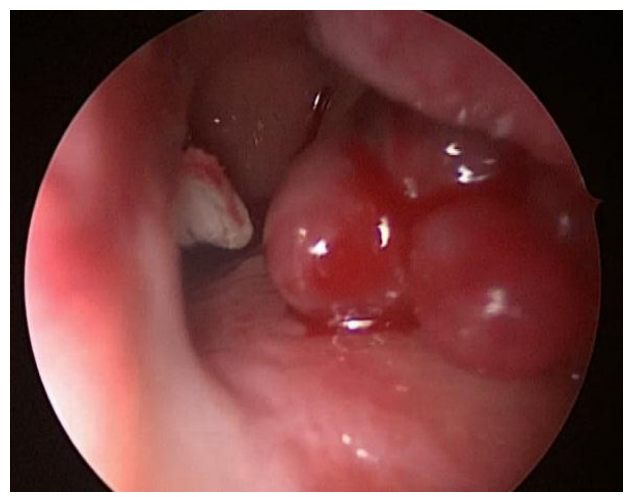

Gambar 1. Gambaran naso-endoskopi hemangioma intranasal di kavum nasi sinistra (preoperatif).

Pada pemeriksaan laboratorium darah didapatkan hemoglobin 13,9 gr/dL ( $\mathrm{N}: 11,5-16 \mathrm{gr} / \mathrm{dL})$, leukosit $7.100 / \mathrm{mm}^{3}\left(\mathrm{~N}: 4.000-10.000 / \mathrm{mm}^{3}\right)$, trombosit $423.000 / \mathrm{mm}^{3}\left(\mathrm{~N}: 150.000-500.000 / \mathrm{mm}^{3}\right)$, hematokrit 40,4\% (N: 37-47\%), prothrombin time (PT) 14,5 detik (N: $11-15$ detik), activated partial thromboplastin time (APTT) 49,3 detik (N: 32-46 detik).

Pada tanggal 6 Juli 2011, dilakukan pemeriksaan $C T$ scan sinus paranasal potongan koronal dan aksial, didapatkan hasil dengan kesan tumor di kavum nasi sinistra posterior dan gambaran sinusitis maksilaris bilateral. Juga terdapat pneumatisasi konka media kanan dan kiri (konka bulosa), dan pneumatisasi septum nasi yang disertai dengan deviasi septum. Tidak tampak erosi pada daerah tulang (gambar 2a-b dan 2c-d).

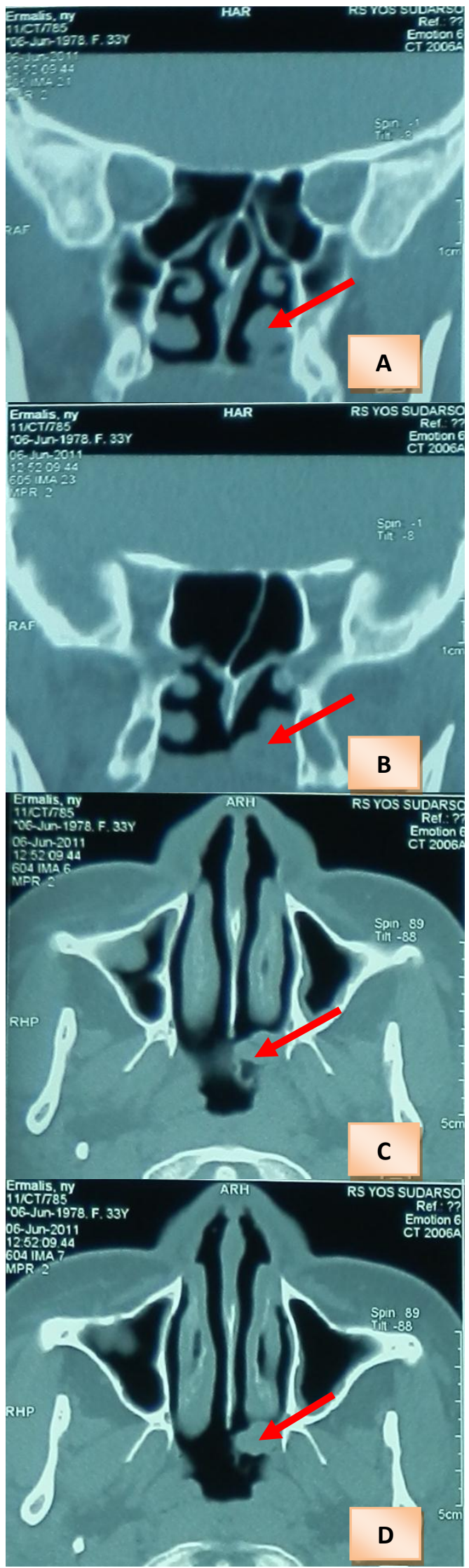

Gambar 2.a-b. CT scan sinus paranasal potongan koronal. c-d. CT scan sinus paranasal potongan aksial. 
Saat itu ditegakkan diagnosis kerja tumor kavum nasi sinistra, curiga hemangioma di dinding lateral hidung dan septum deviasi KNDS, serta rinosinusitis maksilaris bilateral. Pasien dianjurkan dirawat di bagian THT Bedah Kepala Leher untuk persiapan dilakukan tindakan operasi pengangkatan massa tumor. Pasien tidak datang pada hari rawatan.

Tanggal 17 Juni 2011 pasien akhirnya mau dirawat. Pasien dirawat di bagian THT Bedah Kepala Leher RSUP Dr. M. Djamil Padang, untuk direncanakan operasi pengangkatan massa tumor kavum nasi dengan pendekatan endoskopi dan rinosinusitis dengan pendekatan Functional Endoscopy Sinus Surgery (FESS). Tapi pasien menolak untuk dilakukan tindakan operasi FESS, pasien bersedia hanya untuk tindakan pengangkatan massa tumor.

Sehari sebelum dilakukan operasi, informed consent tindakan operasi. Pasien diberikan antibiotika seftriakson injeksi 1x $1 \mathrm{gr}$ intravena. Sebelumnya dilakukan tes kulit. Juga diberikan vitamin $\mathrm{K}$, vitamin $\mathrm{C}$ $1 \times 1$ ampul intravena dan deksametason injeksi $3 \times 5$ $\mathrm{mg}$ iv. Pasien dipuasakan 6-8 jam sebelum operasi. Dipersiapkan darah Packet Red Cell 1 kantong (250 cc). Pasien dikonsulkan ke bagian Anestesiologi.

Pada tanggal 23 Juni 2011, dilakukan operasi pengangkatan massa tumor kavum nasi, curiga hemangioma dengan pendekatan endoskopi. Pasien tidur terlentang di atas meja operasi dalam narkose. Dipasang oral packing. Dilakukan pemasangan tampon lidokain dan adrenalin $4: 1$ selama 10 menit. Evaluasi dengan menggunakan endoskop $0^{0}$, pada kavum nasi dextra tampak lapang, kompleks osteomeatal tampak terbuka, cairan hidung atau pus tidak ada. Kavum nasi sinistra lapang, pada sepertiga posterior tampak massa tumor berwarna kemerahan, licin dan berbenjol-benjol, mudah berdarah.

Dengan menggunakan jarum suntik $5 \mathrm{cc}$, dilakukan infiltrasi dengan adrenalin 1:200.000 pada dasar mukosa KNS bagian posterior, sampai mukosa tampak pucat. Dilanjutkan dengan panduan endoskop $0^{0}$, dilakukan insisi menggunakan pisau sabit (House sickle knife $6.0 \times 1,5 \mathrm{~mm}$ ), pada pinggir tumor secara melingkar. Insisi dilakukan sampai ke dasar tulang. Pinggir mukosa tumor bagian anterior yang melekat ke dinding lateral, dijepit dengan Blakeslay forcep, diputar searah jarum jam, sampai mukosa dan tumor terlepas. Sisa-sisa pinggir mukosa tempat perlengketan dibersihkan dan dikuret dengan curretage sampai dasar tulang terpapar. Perdarahan selama operasi \pm 20-30 cc. Pendarahan diatasi. Dipasang tampon anterior 0-1. Oral packing dibuka. Operasi selesai. Jaringan atau massa tumor diperiksa di Laboratorium Patologi Anatomi (PA).

Pasca operasi pasien dirawat di bangsal THT diberikan terapi seftriakson injeksi $2 x 1$ gram iv, deksametason injeksi $3 \times 5 \mathrm{mg}$ iv, ranitidin injeksi $2 x$ $100 \mathrm{mg}$ iv, tramadol $100 \mathrm{mg}$ dalam 1 kolf Ringer Lactat per 8 jam (diberikan 1 hari saja, selanjutnya analgetik diganti dengan asam mefenamat $3 \times 500 \mathrm{mg}$ po. Tampon anterior hidung dibuka pada hari keempat.

Pada tanggal 27 Juni 2011, tampon anterior hidung dibuka, tidak ada perdarahan. Pasien dibolehkan pulang, diberikan terapi sefiksim $2 x 100$ $\mathrm{mg}$ po, asam mefenamat $3 \times 500 \mathrm{mg}$ po dan metilprednisolon $3 \times 4 \mathrm{mg}$ po.

Tanggal 1 Juli 2011, pasien kontrol pertama kali ke Poliklinik THT. Keluhan hidung berdarah sudah tidak ada. Hidung tersumbat tidak ada. Pada pemeriksaan rinoskopi anterior dan nasoendoskopi pada kavum nasi sinistra ditemukan kavum nasi lapang, krusta minimal, tidak tampak massa (gambar 3).

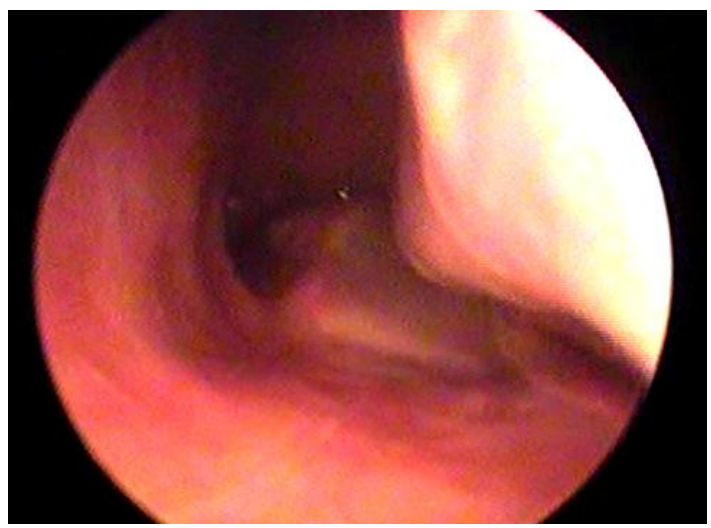

Gambar 3. Kontrol pertama pasca ekstirpasi hemangioma, tidak tampak massa di kavum nasi sinistra.

Hasil pemeriksaan laboratorium PA didapatkan jaringan yang mengalami perdarahan, proliferasi sel-sel endotel dengan rongga-rongga berisi eritrosit. Tampak pula jaringan lemak, jaringan ikat, epitel transisional, kelenjar-kelenjar dan serbukan limfosit. Diagnosis hemangio endotelioma dengan radang kronik (gambar 4 ).

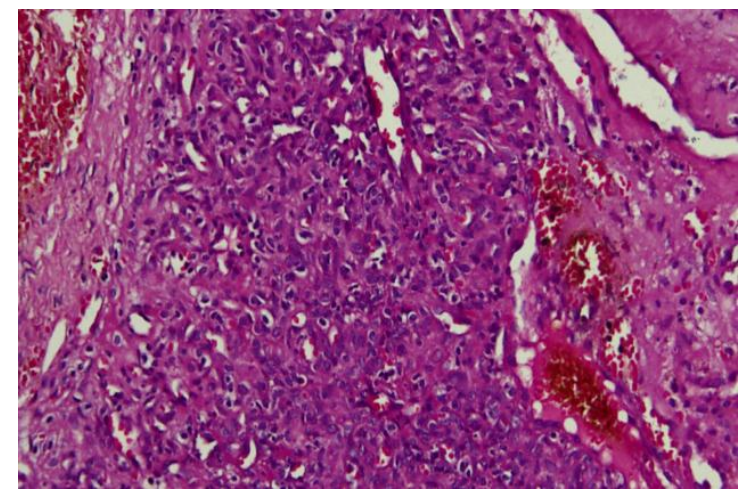

Gambar 4. Gambaran mikroskopis hemangio endotelioma dengan radang kronis. H\&E 40x10.

Diagnosis pasien adalah pasca ekstirpasi hemangioma di dinding lateral hidung hari ke-8. Terapi antibiotika, sefiksim dilanjutkan.

Tanggal 8 Juli 2011, pasien kontrol untuk yang kedua kali. Tidak ada keluhan hidung berdarah, atau hidung tersumbat. Pada pemeriksaan rinoskopi anterior dan nasoendoskopi tidak tampak massa tumor intra nasal. Pasien dianjurkan kontrol jika ada keluhan.

\section{Diskusi}

Telah dilaporkan satu kasus hemangioma intranasal pada seorang wanita berumur 33 tahun. Dikutip dari Bailey, bahwa kasus hemangioma paling banyak ditemukan pada jenis kelamin perempuan dibandingkan laki-laki dengan rasio $6: 1$. $^{4}$ Walaupun dapat mengenai seluruh lapisan usia, hemangioma paling sering muncul pada dekade ke-3 atau ke-4 dari kehidupan. $^{2,7,9}$ Sedangkan menurut Lee dkk, hemangioma di kavum nasi terjadi antara dekade ke-3 
sampai dekade ke-5. ${ }^{10}$ Pada kasus pasien ini, terjadi di dekade ke-3.

Hemangioma daerah kepala dan leher termasuk kasus yang jarang. Stamataki dkk melaporkan, di Johns Hopkins Hospital antara tahun 1980 sampai dengan tahun 2003, terdapat 23 kasus hemangioma daerah kepala dan leher. Dari jumlah tersebut hanya terdapat 1 kasus hemangioma intranasal, yang telah menyebabkan erosi pada tulang intranasal dan tulang ethmoid. ${ }^{6}$

Di kavum nasi, tampilan klinis hemangioma sering berupa sebuah nodul berukuran $3 \mathrm{~cm}$ (bervariasi 1-8 cm). Tidak hanya timbul pada septum tapi juga pada dinding lateral hidung. Hemangioma septum ( $45 \%$ dari total kasus hemangioma intranasal), sedangkan hemangioma di dinding lateral hidung dan vestibulum nasi sekitar $17,5 \% .^{11}$

Epistaksis yang berulang dan hidung tersumbat merupakan gekala klinis paling sering dari hemangioma intranasal. ${ }^{4,10,12}$ Dikutip dari Nedev, epistaksis unilateral merupakan keluhan terbanyak yaitu sebesar $93 \%$ dan sumbatan hidung sebanyak $35 \%$. Pada pasien ini hidung sering berdarah terjadi setelah 3 bulan terakhir. Perkembangan hemangioma, walaupun jinak sering bersifat progresif sehingga menyebabkan perdarahan yang berulang. ${ }^{3,4}$

Penggunaan CT scan dalam membantu menegakkan diagnosis hemangioma intranasal. Tidak hanya membantu mengidentifikasi bagian awal atau asal dari hemangioma, perluasan tumor, tapi juga digunakan sebagai alat kontrol prognosis atau mendeteksi rekurensi. ${ }^{10,13}$ Permintaan CT scan untuk hemangioma di kavum nasi adalah potongan koronal aksial dengan ketebalan irisan 2-3 mm. Menurut Lee dkk, hal penting yang harus dinilai pada CT scan hemangioma intranasal ini adalah apakah sudah ada terjadi erosi tulang. ${ }^{10}$

Pemeriksaan laboratorium darah pada pasien ini dilakukan untuk melihat adanya kemungkinan kelainan sistemik. Didapatkan semua hasil pemeriksaan dalam batas normal. Kecuali nilai APTT sedikit memanjang yaitu 49,3 detik (N: 32-46 detik). Peningkatan waktu tergolong ringan (slightly prolonged). Sedangkan tujuan pemberian vitamin $\mathrm{K}$ dan vitamin $C$ sebagai tindakan pencegahan (profilaks) atau pada kasus dengan gangguan hemostasis masih memerlukan penelitian lebih lanjut. PT yang memanjang menunjukkan adanya kelainan pada jalur ekstrinsik dari proses pembekuan darah. Vitamin $\mathrm{K}$ berpengaruh terhadap faktor II (prothrombin), VII, IX dan X. Jadi vitamin K lebih bermakna pemberiannya salah satunya pada kasus dengan PT yang memanjang. ${ }^{14}$ Vitamin $C$, seperti yang dilakukan penelitian oleh Tofler dkk, tidak memberikan pengaruh yang bermakna pada proses koagulopati darah. Tapi bermakna pada penurunan kadar lipid dalam serum. ${ }^{15}$

Obat-obatan golongan kortikosteroid digunakan pada kasus hemangioma intranasal agar proses proliferasi sel endotel pembuluh darah yang berlangsung cepat, dapat dihambat. Dikutip dari Bailey, pemberian kortikosteroid sistemik diberikan selama 3-4 minggu, lalu tapering off. ${ }^{4}$

Umumnya hemangioma tidak memerlukan tindakan yang segera. Sekitar $20-40 \%$ pasien yang dilakukan tindakan operatif akan mengalami hemangioma yang berulang. ${ }^{11}$ Menurut Elhamd, angka kekambuhan untuk hemangioma intranasal ini adalah sekitar $15 \%$. ${ }^{16}$ Tindakan bedah direkomendasikan ketika hemangioma sudah mengganggu secara fungsi dan gangguan estetika. ${ }^{11}$

Pada kasus hemangioma intranasal atau sinus paranasal, pendekatan dari luar (external approach) sering dilakukan untuk memudahkan kontrol perdarahan selama operasi berlangsung. Sehingga akses menuju pengangkatan tumor yang komplit semakin mudah. Kelemahan pendekatan endoskopi adalah kesulitan dalam mengontrol perdarahan, sehingga batas-batas tumor sulit dinilai. Tapi dengan persiapan yang adekuat serta kontrol perdarahan selama operasi yang baik, pendekatan endoskopi pada kasus hemangioma intranasal dapat dilakukan dengan sukses. $^{13}$

Berikut adalah beberapa pilihan terapi pada hemangioma di daerah kepala dan leher yaitu::,4,1

1) Intranasal injections of sclerosing solution.

Skleroterapi efektif hampir pada 90\% kasus hemangioma di daerah bibir dan mata.

2) Injeksi steroid intralesi.

Efektif pada hemangioma subkutaneus dan berukuran kecil. Efek samping tindakan dapat berupa oklusi arteri retina sentralis, nekrosis kulit, dan supresi adrenal.

3) Subcutaneus interferon application.

Interferon-alfa 2-a atau 2-b dinilai paling efektif. Efek samping berupa demam, malaise, nefritis dan anemia hemolitik.

4) Kortikosteroid sistemik.

Dapat diberikan prednison $5 \mathrm{mg} / \mathrm{kgBB} /$ hari untuk 6-9 minggu, dilanjutkan 2-3 $\mathrm{mg} / \mathrm{kgBB} /$ hari selama 4 minggu. Waspadai efek samping terhadap penyakit hipertensi, diabetes melitus, dan fenomena rebound.

5) LASER

Cukup efektif untuk hemngioma yang masih intak atau sudah terjadi ulserasi.

6) Cryosurgery and $x$-ray therapy.

Cryosurgery banyak diminati di Eropa dan Amerika Selatan. Tapi efek samping timbulnya skar pada hemangioma superfisial.

7) Sitostatik.

Pada kasus hemangioma yang sudah tidak mempan dengan pemberian kortikosteroid, pemberian vinkristin dapat menjadi suatu pilihan.

8) Embolisasi.

Untuk hemangioma yang luas atau terapi pendahuluan sebelum dilakukan terapi pembedahan.

Terapi pembedahan dengan pendekatan endoskopi ini harus mempertimbangkan hal-hal seperti tampilan klinis, riwayat penyakit sebelumnya, ukuran dan lokasi hemangioma.,11

Pemakaian alat unipolar suction cautery, mikrodebrider dan forsep Blakesly akan lebih memberikan hasil yang baik. ${ }^{13}$

Pasien hemangioma pasca tindakan operatif harus diikuti perkembangannya sampai 5 tahun. Interval kontrol adalah tiap 3 bulan. CT scan sebagai alat kontrol dilakukan 18 bulan pasca operasi. ${ }^{13}$ Sedangkan menurut Tseng kontrol pasien hemangioma pasca tindakan operatif dilakukan sampai 36 bulan. ${ }^{17}$ Sarmento juga menyatakan CT scan dilakukan 18 bulan pasca operasi pada kasus hemangioma sinonasal. ${ }^{18}$ 


\section{Daftar Pustaka}

1. Miller FR, D'agostino MA, Schlack K. Lobular Capillary Hemangioma of Nasal Cavity. Otolaryngol Head Neck Surg May 1999; 120: 783-4.

2. Karakus MF, Ozcan KM, Bilal N, Dere H, Erekul S. Pediatric Lobular Capillary Hemangioma Accompanied with a Foreign Body in the Nasal Cavity. Int J Pediatr Otorhinolaryngol. 2007; 2: 231-4.

3. Simic R, Vlahovic A, Subarevic V. Treatment of Nasal Hemangiomas. Int J Pediatr Otorhinolaryngol. 2009; 73: 1402-6.

4. Duvvuri U, Carrau RL, Kassam AB. Vascular Tumors of the Head and Neck. In: Bailey BJ, Johnson JT et al editors. Otolaryngology Head and Neck Surgery, $4^{\text {th }}$ Ed Vol 1. Philadelphia : Lippincott Williams \& Wilkins, 2006. p. 1812-25

5. Jackson IT, Sosa J. Excision of Nasal Tip Hemangioma via Open Rhinoplasty - a Skin Sparing Technique. Eur J Plast Surg 1998; 21:265-8.

6. Stamataki S, Francis HW, Holliday M, McCarthy E. Histological Features of Osteofibrous Hemangioma of the Maxillofacial and Skull Base Regions. Otolaryngol Head Neck Surg 2008; 138: 587-93.

7. Nair LCS, Bahal MA, Bhadauria CRS. Lobular Capillary Hemangioma of Nasal Cavity. MJAFI 2008; 64: 270-1.

8. Pasquini E, Sciarretta V, Frank G, Cantaroni C, Modugno GC, Mazzatenta D et al. Endoscopic Treatment of Benign Tumors of the Nose and Paranasal Sinuses. Otolaryngol Head Neck Surg 2004; 131: 180-6.

9. Ozcan C, Apa DD, Gorur K. Pediatric Lobular Capillary Hemangioma of the Nasal Cavity. Eur Arch Otorhinolaryngol 2004; 261(8):449-51.
10. Lee DG, Lee SK, Chang HW, Kim JY, Lee HJ, Kwon JH, et al. CT Features of Lobular Hemangioma the Nasal Cavity. Am J Neuroradiol 2010; 31:749-54.

11. Nedev P. Lobular Capillary Haemangioma of the Nasal Cavity in Children. Trakia Journal of Science 2008; 6(1):63-7.

12. Chalian AA, Litman D. Neoplasms of the Nose and Paranasal Sinuses. In : Snows JB, editor. Ballenger's Manual of Otorhinolaryngology Head and Neck Surgery. 2002. London : BC decker, p. 304-14.

13. Kelley TF. Endoscopic Management of an Intranasal Hemangioma : a Case Report and Literatur Review. Otolaryngol Head Neck Surg 2003; 128: 595-7.

14. Activated Partial Thromboplastin Time (APTT). Available from URL: http://labtestsonline.org/understanding/analytes/a ptt/tab/test , Article last update July 24, 2011. July 2011.

15. Toffler GH, Stec JJ, Stubbe I, Beadle J, Feng D. Lipinska I, Taylor A. The Effect of Vitamin C Supplementation on Coagulability and Lipid Levels in Healthy Male Subjects. Thrombosis Research 2000; 100(1):35-41.

16. Elhamd KEAA. Lobular Capillary Hemangioma of the Nose, a Report of Two Cases. Saudi Journal of Otorhinolaryngology Head and Neck Surgery 2008; 10(2):48-50.

17. Tseng CC, Tsay SH, Tsai TL, Shu CH. Epitheloid Hemangioendothelioma of the Nasal Cavity. J Chin Med Assoc 2005; 68(1):45-8.

18. Sarmento KS. Endoscopic Resection of a Sinonasal Cavernous Hemangioma. 2004. 